\title{
Hemorragia retroperitoneal por angiomiolipoma renal
}

\author{
Duque Fernández de Vega S, González Ortega FJ, Moreno Torres C, López Marín P, \\ Tinaut Renera FJ *.
}

Servicios de Radiodiagnóstico y Urología*. Hospital Clínico San Cecilio. Granada.

Actas Urol Esp. 2008;32(6):670

Paciente varón de 75 años que seguía controles en la consulta de Urología por presentar en porción posteroinferior de riñón izquierdo una lesión redondeada de $4 \mathrm{~cm}$ de diámetro caracteriza mediante ecografía y TC de angiomiolipoma. No presentaba otras patologías de interés.

Acude a urgencias con mal estado general, sudoración, palidez, hipotensión y con clínica de abdomen agudo. Se realiza placa simple de abdomen en la que se observa un aumento de densidad en todo el flanco izquierdo borra silueta renal, asocia pérdida de la aireación intestinal normal a este nivel y provoca mala delimitación de la línea del psoas homolateral (Fig. 1).

Ante los hallazgos anteriores se solicita estudio ecográfico en el que a nivel de fosa renal izquierda encontramos en lugar del riñón, una gran masa de sonoestructura heterogénea que se extiende caudalmente hasta zona de cresta iliaca y algunas lengüetas de líquido libre intraabdominal (Fig. 2).

Para caracterizar mejor la lesión, se realiza TC abdominopélvico basal en el que visualizamos una masa heterogénea con centro de densidad grasa que por los antecedentes correspondía con el angiomiolipoma conocido. Adyacente a éste se observa una gran hemorragia perirrenal que desplaza anteriormente al riñón izquierdo con extensión hacia espacios retroperitoneales inferiores (Fig. 3).

El paciente fue operado de urgencias extirpándose el riñón conteniendo el angiomiolipoma sangrante y realizando lavado retroperitoneal. La pieza quirúrgica se analizó y confirmó el diagnóstico radiológico.

Correspondencia autor: Dra. S. Duque Fernández de Vega Servicio de Radiodiagnóstico. Hospital Clínico San Cecilio Avda. del Dóctor Olóriz, 16 - 18012 Granada. Tel.: 958023308

E-mail autor: sandraduquefv@gmail.com

Información artículo: Imágenes en Urología

Trabajo recibido: diciembre 2006

Trabajo aceptado: enero 2007

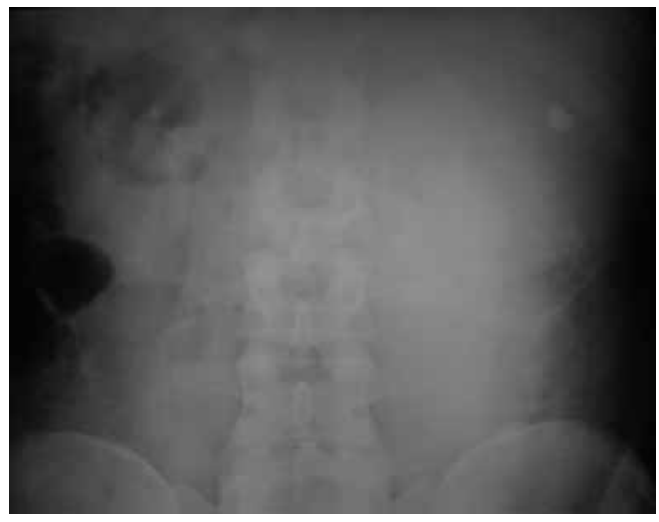

FIGURA 1

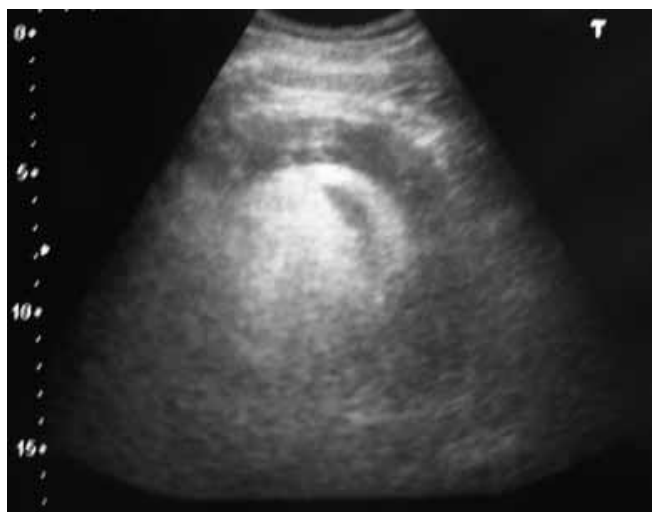

FIGURA 2

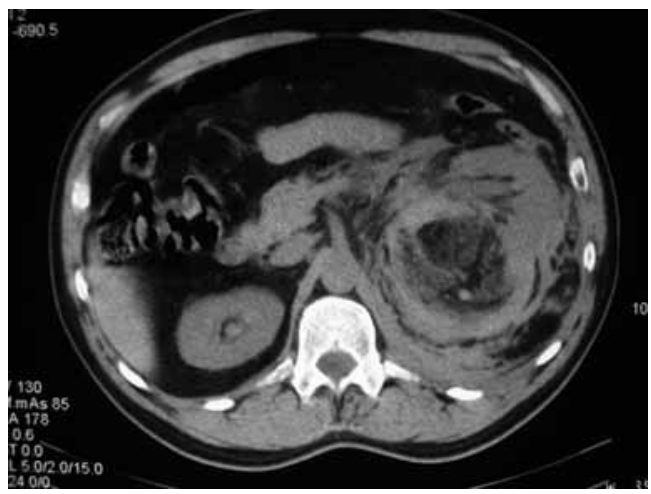

FIGURA 3 